\title{
Germination of Spores of Micromonospora chalcea: Physiological and Biochemical Changes
}

\author{
By JUAN E. SUAREZ, COVADONGA BARBES AND \\ CARLOS HARDISSON* \\ Departamento de Microbiologia, Facultad de Medicina, Universidad de Oviedo, \\ Oviedo, Spain
}

(Received 24 January 1980; revised 29 April 1980)

\begin{abstract}
Germinating spores of Micromonospora chalcea pass through three morphological stages: darkening, swelling and germ tube emergence. The process of germination has $\mathrm{pH}$ and temperature optima of 8.0 and $40^{\circ} \mathrm{C}$, respectively, and is not affected by activation treatments. Darkening, accompanied by a loss of heat resistance and refractility and a decrease in absorbance of the dormant spores, needs only energy, which can be obtained from endogenous sources, and exogenous cations. Agents that inhibit ATP formation block darkening, but inhibitors of macromolecular synthesis do not affect it. Swelling requires exogenous carbon but not nitrogen sources and is characterized by a 30 to $40 \%$ increase in spore diameter. RNA synthesis is necessary for swelling and inhibitors of protein synthesis delay this process. During this stage, maximum respiratory, cytochrome oxidase and catalase activities are reached. DNA synthesis starts at the beginning of germ tube emergence. This final stage requires both exogenous carbon and nitrogen sources and the sequence of macromolecular synthesis is RNA, protein and, finally, DNA. Rifampicin, streptomycin and mitomycin $\mathrm{C}$ prevent protein and DNA synthesis regardless of when added during germination. Rifampicin inhibits $\left[{ }^{3} \mathrm{H}\right]$ uridine incorporation immediately but there is a delay of about $160 \mathrm{~min}$ in the case of streptomycin or mitomycin $\mathrm{C}$.
\end{abstract}

\section{INTRODUCTION}

The genus Micromonospora has a complex developmental cycle in which a monopodially branched mycelium, divided at intervals by cross-walls, develops from one asexual spore. On this mycelium sessile spores or spores on short sporophores are produced, either singly or in pairs; under appropriate conditions, these germinate and repeat the cycle. This developmental cycle is of interest as a simple model of a process of cellular differentiation. Germination is the process of converting a dormant spore into a metabolically active vegetative form and includes changes in the morphology, physiology and biochemistry of the resting structure. The physiological characteristics of the process in actinomycetes are well established in species of the genus Streptomyces (Attwell \& Cross, 1973; Ensign, 1978; Hardisson et al., 1978; Mikulik et al., 1977). There have been no studies of germination in species of the genus Micromonospora which includes several antibiotic synthesizers.

This paper deals with the physiological and biochemical changes which take place during the germination of spores of Micromonospora chalcea. 


\section{METHODS}

Strain and culture conditions. Micromonospora chalcea ATCC 12542 was grown for $20 \mathrm{~d}$ at $28^{\circ} \mathrm{C}$ in $250 \mathrm{ml}$ flasks containing $75 \mathrm{ml} \mathrm{GAE}$ solid medium [consisting of (\%, w/v): $\mathrm{K}_{2} \mathrm{HPO}_{4}, 0.05 ; \mathrm{MgSO}_{4} .7 \mathrm{H}_{2} \mathrm{O}$, $0.05 ; \mathrm{FeSO}_{4} .7 \mathrm{H}_{2} \mathrm{O}, 0.001$; glucose, 1 ; asparagine, 0.1 ; yeast extract, 0.05 ; agar, 2].

Influence of physical and chemical agents on germination. Spore suspensions were prepared as described previously (Hardisson et al., 1978). Freshly harvested spores were germinated in $10 \mathrm{ml} \mathrm{GAE}$ liquid medium in $100 \mathrm{ml}$ flasks at $35^{\circ} \mathrm{C}$ and $200 \mathrm{rev} . \mathrm{min}^{-1}$ in a Gallenkamp orbital incubator. The influence of temperature, $\mathrm{pH}$, nutrients and inhibitors on germination were tested as described previously (Hardisson et al., 1978). To follow the process of germination, the percentage of spores in different morphological stages was determined using a Thoma chamber and variations in the absorbance of the spore suspensions were measured. Suspensions were adjusted to about $4 \times 10^{8}$ spores $\mathrm{ml}^{-1}\left(A_{580}=0 \cdot 3\right)$.

Decimal reduction time ( $D$-value). Portions $(1 \mathrm{ml})$ of a spore suspension in water in sealed glass ampoules $\left(A_{580}=0.3\right)$ were separately heated at temperatures ranging from 75 to $90^{\circ} \mathrm{C}$. At 5 min intervals, up to $30 \mathrm{~min}$, samples were removed, rapidly cooled, and numbers of survivors were counted by plating. The slope of the survival curve at each temperature was used to determine the decimal reduction time (D-value), i.e. the time required for the number of survivors to decrease by a factor of 10 . To determine the heat resistance of spore suspensions at different temperatures, the $Z$-value was calculated as the change in temperature necessary to change the D-value by a factor of 10 (Gould, 1971).

Respiratory measurements. Oxygen determinations and cytochrome oxidase and catalase activities were measured in an YSI model 53 Biological Oxygen Monitor equipped with a Clark oxygen electrode (Yellow Springs Instruments Co., Yellow Springs, Ohio, U.S.A.) as described previously (Hardisson et al., 1978), except that the spore suspension contained $4 \times 10^{8}$ spores $\mathrm{ml}^{-1}$.

Rate of synthesis and total amount of macromolecules. The rates of synthesis of RNA, protein and DNA were determined by measuring the incorporation of labelled precursors into trichloroacetic acid-precipitable macromolecules during germination as described previously (Hardisson et al., 1978). The total amounts of macromolecules were determined using $60 \mathrm{ml}$ suspensions containing $4 \times 10^{8}$ spores $\mathrm{ml}^{-1}$. Samples were taken every $60 \mathrm{~min}$ for $8 \mathrm{~h}$. Extraction procedures were as described previously (Hardisson et al., 1978). DNA was assayed using the diphenylamine method (Burton, 1956), RNA was determined by the orcinol method (Schneider, 1957) and protein was measured by the Lowry method.

\section{RESULTS}

Spore resistance to temperature and staining by basic dyes

Dormant spores of $M$. chalcea showed considerably higher heat resistance than vegetative forms. They were completely resistant to temperatures below $75^{\circ} \mathrm{C}$, but above this temperature, small increases produced great decreases in viability (Fig. 1). The resistance of the spores to temperature was established from the thermal reduction curve obtained by plotting the different decimal reduction times against temperature: by this method a $\mathrm{Z}$-value of $12.5^{\circ} \mathrm{C}$ was obtained. Heat resistance was completely lost during darkening. Dormant spores were not stained by basic dyes such as methylene blue; spore darkening was accompanied by an increase in sensitivity to stains with a good correlation between the number of dark and stainable spores.

\section{Morphological, absorbance and dry weight changes during germination}

Dormant spores of $M$. chalcea appeared bright with a distinct dark margin. When placed in conditions favourable for germination they became completely dark with a maximum after about 2 to $3 \mathrm{~h}$ incubation (Table 1). The darkening of spores was accompanied by a 30 to $35 \%$ decrease in the absorbance of the spore suspension (Fig. 2). The spores then began to swell, reaching a diameter of 130 to $140 \%$ of the initial value after about $5 \mathrm{~h}$ incubation. Germ tubes began to emerge after about $6 \mathrm{~h}$ incubation. As a consequence of swelling and germ tube emergence, the absorbance of the suspension increased linearly after $3 \mathrm{~h}$ incubation. The dry weight of the spores did not change until after about $5 \mathrm{~h}$ germination when outgrowth occurred (Fig. 2). After that, dry weight increased linearly 


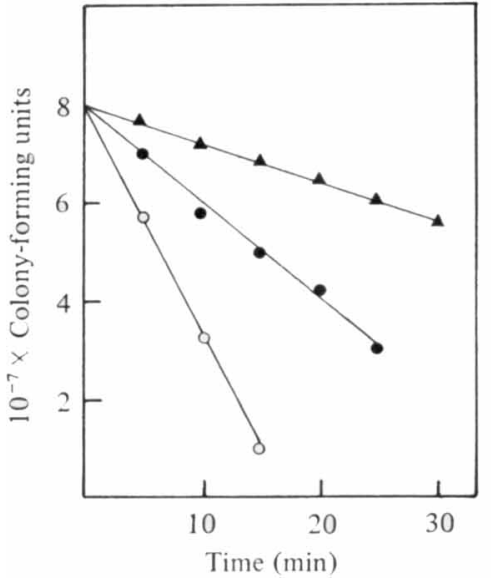

Fig. 1

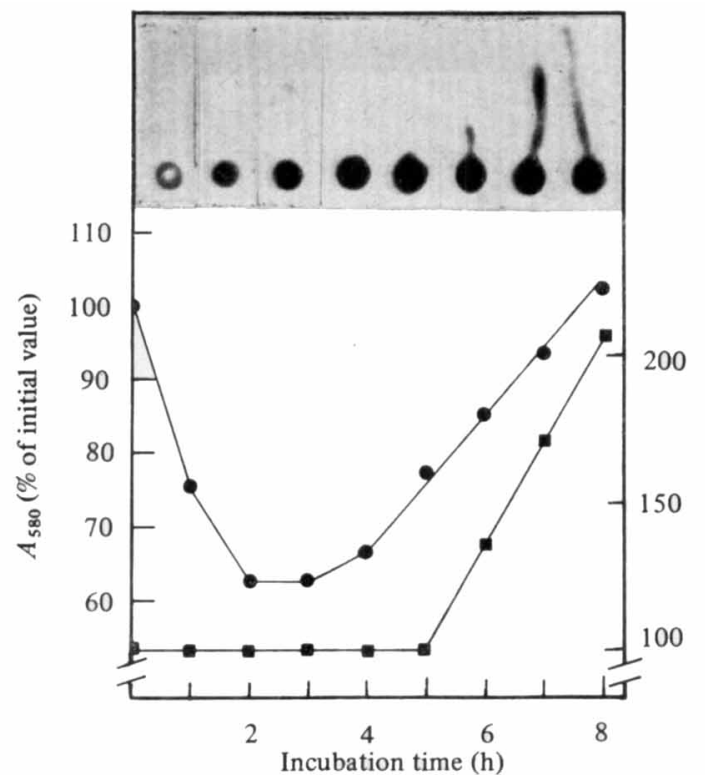

Fig. 2

Fig. 1. Heat resistance of Micromonospora chalcea dormant spores. From these survival curves the following D-values (min) were obtained: $\Delta, 80^{\circ} \mathrm{C}, \mathrm{D}=12 \cdot 5 ; 0,85^{\circ} \mathrm{C}, \mathrm{D}=5 \cdot 0 ; 0,90^{\circ} \mathrm{C}$, $\mathbf{D}=2 \cdot 0$.

Fig. 2. Morphological, absorbance (O) and dry weight ( $\square$ ) changes during germination of Micromonospora chalcea spores in GAE liquid medium. The micrographs indicate the sequential morphological stages during germination. The initial absorbance was $\mathbf{0 \cdot 3}$. Dry weights were determined with $4 \times 10^{10}$ spores per sample by direct weighing of the cells after drying to constant weight. Each point was determined in quintuplicate.

Table 1. Percentage of different morphological stages during germination of Micromonospora chalcea spores

Spore suspensions $(10 \mathrm{ml})$ were incubated in GAE liquid medium in $100 \mathrm{ml}$ flasks at $35^{\circ} \mathrm{C}$ and $200 \mathrm{rev}$. $\mathrm{min}^{-1}$. Results were calculated from observations of 200 spores at each time in four independent experiments.

Percentage of spores at each morphological stage

\begin{tabular}{|c|c|c|c|c|c|c|c|c|c|}
\hline \multirow{2}{*}{$\begin{array}{l}\text { Morphological } \\
\text { stage }\end{array}$} & \multicolumn{9}{|c|}{ Incubation time $(\mathrm{h})$ : } \\
\hline & 0 & 1 & 2 & 3 & 4 & 5 & 6 & 7 & 8 \\
\hline Dormant & 100 & $62 \cdot 5 \pm 2 \cdot 5$ & $45 \pm 5$ & $35 \pm 5$ & $27 \cdot 5 \pm 2 \cdot 5$ & $15 \pm 5$ & $9 \pm 1$ & $7 \cdot 5 \pm 2 \cdot 5$ & $7 \cdot 5 \pm 2 \cdot 5$ \\
\hline Dark & 0 & $37 \cdot 5 \pm 2 \cdot 5$ & $55 \pm 5$ & $60 \pm 5$ & $47 \cdot 5 \pm 2 \cdot 5$ & $30 \pm 5$ & $22 \cdot 5 \pm 2 \cdot 5$ & $\frac{1}{0}$ & 0 \\
\hline Swollen* & 0 & $\overline{0}$ & 0 & $7 \cdot 5 \pm 2 \cdot 5$ & $17 \cdot 5 \pm 2 \cdot 5$ & $50 \pm 5$ & $45 \pm 5$ & $35 \pm 5$ & $22 \cdot 5 \pm 2 \cdot 5$ \\
\hline $\begin{array}{l}\text { With germ } \\
\text { tubes }\end{array}$ & 0 & 0 & 0 & 0 & 0 & $7 \cdot 5 \pm 2 \cdot 5$ & $22 \cdot 5 \pm 2 \cdot 5$ & $50 \pm 5$ & $70 \pm 5$ \\
\hline
\end{tabular}

* Diameter at least $1 \cdot 3$ times the original spore diameter.

$\dagger$ Germ tube at least as long as the diameter of the swollen spore.

as a consequence of the active biosynthesis accompanying germ tube appearance and growth. About $10 \%$ of the spores did not germinate in these conditions.

\section{Effect of physical and chemical agents on germination}

Effect of temperature. The effect of temperature on the germination rate was determined by plotting the percentage of spores with germ tubes at different times. The number of 

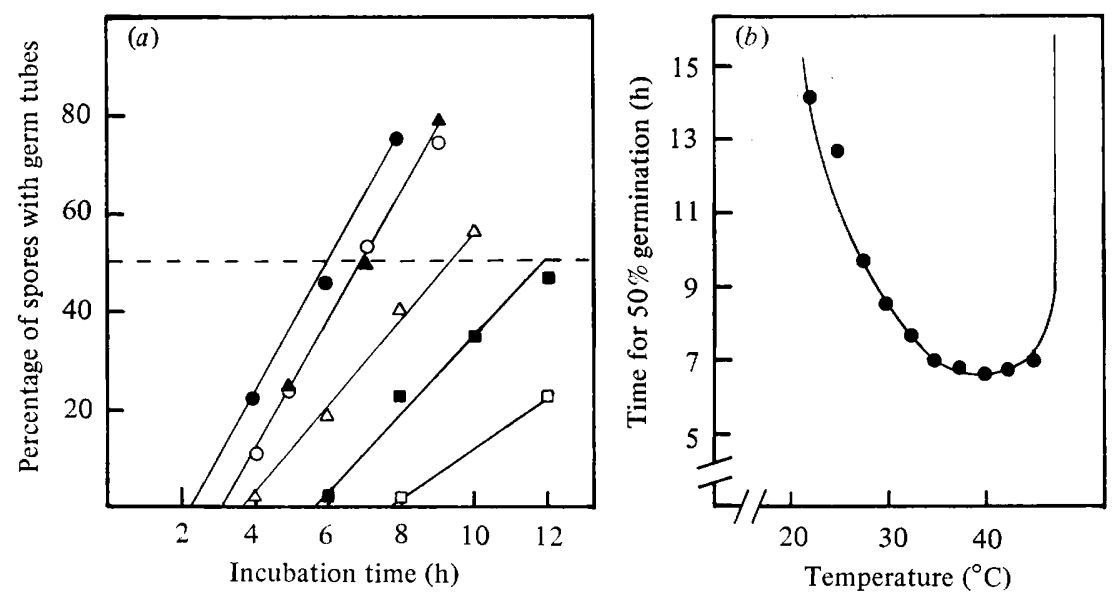

Fig. 3. Effect of temperature on germ tube formation in Micromonospora chalcea. (a) Increase in the percentage of spores forming germ tubes during incubation in GAE liquid medium at $20^{\circ} \mathrm{C}$ $(\square), 25^{\circ} \mathrm{C}(\square), 30^{\circ} \mathrm{C}(\triangle), 35^{\circ} \mathrm{C}(\Delta), 40^{\circ} \mathrm{C}(\bigcirc)$ and $45^{\circ} \mathrm{C}(\bigcirc)$. (b) Minimum time required for $50 \%$ of spores to form germ tubes, using data from $(a)$. Data corresponding to $22 \cdot 5,27 \cdot 5,32 \cdot 5$, $37.5,42.5$ and $47.5^{\circ} \mathrm{C}$ are not shown in (a). At 20 and $47.5^{\circ} \mathrm{C}$ germination was too slow to be measured.

spores with germ tubes increased proportionally with time (Fig. $3 a$ ) giving straight lines, the slopes of which corresponded to the different rates of germination. The minimum time required for $50 \%$ of the spores to produce germ tubes was chosen as a measure of the germination; the representation of these values (Fig. $3 b$ ) shows that the optimum temperature was between 35 and $45^{\circ} \mathrm{C}$ with a maximum at about $40^{\circ} \mathrm{C}$ and with germination limits between $22^{\circ} \mathrm{C}$ and $45^{\circ} \mathrm{C}$.

Effect of $p H$. Optimum germination of $M$. chalcea spores was obtained at $\mathrm{pH} 8.0$ and

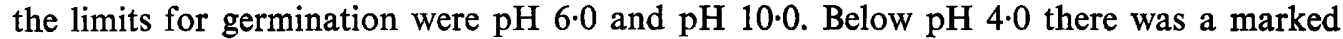
lysis of the spores. Different buffers at the same $\mathrm{pH}$ had a similar effect on the germination: citrate or phosphate buffers at $\mathrm{pH} 6.0$, and Tris $/ \mathrm{HCl}$ and phosphate buffers at $\mathrm{pH} 8.0$ were tested.

Effect of nutrients and inhibitors. Micromonospora chalcea spores did not initiate germination in distilled water or in $0 \cdot 1 \mathrm{M}$-sodium phosphate buffer (pH 7.0). Separate addition of cations such as $\mathrm{Mg}^{2+}, \mathrm{K}^{+}$and $\mathrm{Fe}^{2+}$ at $0.001 \%$ (w/v) final concentration, or suspension in $0.1 \mathrm{M}$-potassium phosphate buffer ( $\mathrm{pH} \mathrm{7.0)}$, resulted in a darkening of spores, swelling of about $30 \%$ of them and formation of germ tubes by about $12 \%$ (Table 2), indicating that dormant spores must contain reserve substances. The results were similar when the salts of GAE medium were used. Respiratory inhibitors such as sodium azide (5 mM), potassium cyanide ( $2.5 \mathrm{mM})$, EDTA $(1.25 \mathrm{mM})$ and 2,4-dinitrophenol $(0.5 \mathrm{~mm})$ completely inhibited spore darkening; on the other hand, inhibitors of macromolecular synthesis (rifampicin, actinomycin D, streptomycin or mitomycin $\mathrm{C}$, each at $5 \mu \mathrm{g} \mathrm{ml}^{-1}$ ) did not affect darkening. Spore swelling was increased when glucose was added to the salts medium, but nitrogen plus salts had no effect (Table 2). Inhibitors of RNA synthesis prevented the swelling of spores and those of protein synthesis retarded it. Germ tube emergence needed both exogenous carbon and nitrogen sources; ammonium was a better nitrogen source than nitrate (Table 2). The effect of adding 12 different carbon compounds at $1 \%(\mathrm{w} / \mathrm{v})$ final concentration to the salts of GAE medium plus $\left(\mathrm{NH}_{4}\right)_{2} \mathrm{SO}_{4}(0 \cdot 2 \%$, w/v) was tested. Six of these compounds (lactose, galactose, mannitol, sucrose, raffinose, maltose and melibiose) gave similar results to glucose (germ tubes grew from about $50 \%$ of the spores after $8 \mathrm{~h}$ incubation), whereas with starch, cellobiose, xylose, arabinose and fructose, few 


\section{Table 2. Effect of nutrients on germination of Micromonospora chalcea spores}

Observations were made after $8 \mathrm{~h}$ incubation at $35^{\circ} \mathrm{C}$ and $200 \mathrm{rev} . \mathrm{min}^{-1}$ in three independent experiments.

Percentage of spores at each morphological stage

\section{Nutrient}

Distilled water

Cations $\left(\mathrm{Mg}^{2+}, \mathrm{K}^{+}\right.$or $\left.\mathrm{Fe}^{2+}\right)(0.001 \%)$

Salts (as in GAE medium)

Salts $+\left(\mathrm{NH}_{4}\right)_{2} \mathrm{SO}_{4}(0 \cdot 2 \%)$

Salts + glucose $(1 \%)$

Salts + glucose $(1 \%)+\mathrm{NaNO}_{3}(0.2 \%)$

Salts + glucose $(1 \%)+\left(\mathrm{NH}_{4}\right)_{2} \mathrm{SO}_{4}(0.2 \%)$

GAE medium

$\begin{array}{cccc}\text { Dormant } & \text { Dark } & \text { Swollen } & \begin{array}{c}\text { With germ } \\ \text { tubes }\end{array} \\ 100 & 0 & 0 & 0 \\ 16 \pm 4 & 42 \pm 4 & 31 \cdot 5 \pm 3 \cdot 5 & 11 \cdot 5 \pm 3 \cdot 5 \\ 18 \pm 2 & 39 \cdot 5 \pm 2 \cdot 5 & 31 \pm 5 & 13 \cdot 5 \pm 1 \cdot 5 \\ 17 \cdot 5 \pm 2 \cdot 5 & 35 \pm 5 & 30 \pm 4 & 16 \pm 2 \\ 15 \cdot 5 \pm 3 \cdot 5 & 17 \cdot 5 \pm 2 \cdot 5 & 48 \pm 3 & 18 \pm 2 \\ 17 \pm 3 & 23 \cdot 5 \pm 3 \cdot 5 & 31 \cdot 5 \pm 3 \cdot 5 & 28 \pm 2 \\ 13 \pm 3 & 21 \pm 3 & 22 \pm 4 & 47 \cdot 5 \pm 2 \cdot 5 \\ 7 \cdot 5 \pm 2 \cdot 5 & 0 & 22 \cdot 5 \pm 2 \cdot 5 & 70 \pm 5\end{array}$

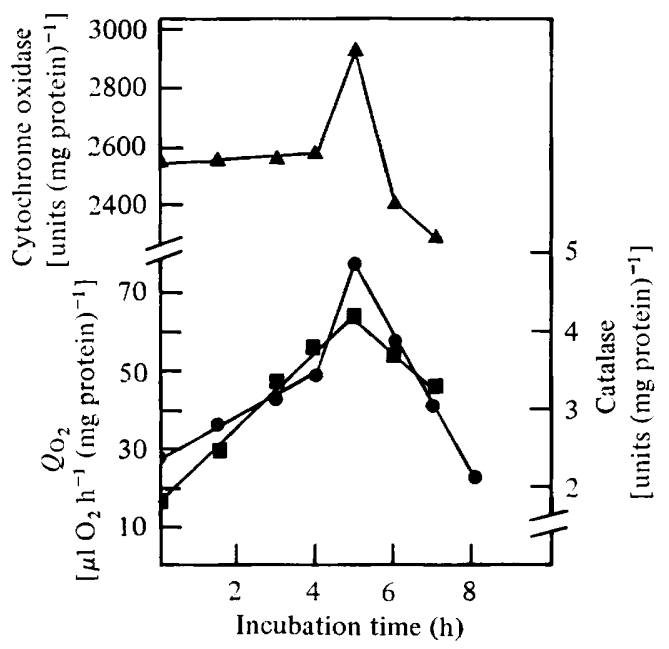

Fig. 4. $Q_{\mathrm{O}_{2}}(\boldsymbol{O})$, cytochrome oxidase $(\boldsymbol{\Delta})$ and catalase ( $\square$ ) activities during germination of $M$ icromonospora chalcea spores. All results were corrected by subtracting the endogenous activities without substrate. Each point was determined in triplicate. The standard deviations were $< \pm 0.5$ for $Q_{\mathrm{O}_{2}}$ values, $< \pm 0.13$ for catalase activities and $< \pm 3.6$ for cytochrome oxidase activities.

or no germ tubes were formed. Seventeen L-amino acids $(0 \cdot 2 \%, \mathrm{w} / \mathrm{v})$ were also tested as sole nitrogen sources. Those giving a higher number of germ tubes than GAE salts plus glucose were alanine, proline, leucine, isoleucine, glutamic and aspartic acid. Addition of glycine, threonine, arginine, cysteine, phenylalanine, asparagine, serine, methionine, tryptophan, cystine and histidine did not modify the results obtained in GAE salts plus glucose. When yeast extract $(0.1 \%, \mathrm{w} / \mathrm{v})$ was added to the salts of GAE medium, germination occurred as in GAE.

\section{$Q_{\mathrm{O}_{2}}$, cytochrome oxidase and catalase activities during germination}

All these activities reached a maximum after about $5 \mathrm{~h}$ incubation (Fig. 4) coinciding with maximum number of swollen spores (Table 1). Germ tube emergence was accompanied by a decrease in all these activities.

\section{Synthesis of macromolecules}

The synthesis of macromolecules was determined by incorporation of exogenous labelled precursors (Fig. $5 a$ ) and by chemical methods (Fig. $5 b$ ). The sequence of macromolecular 

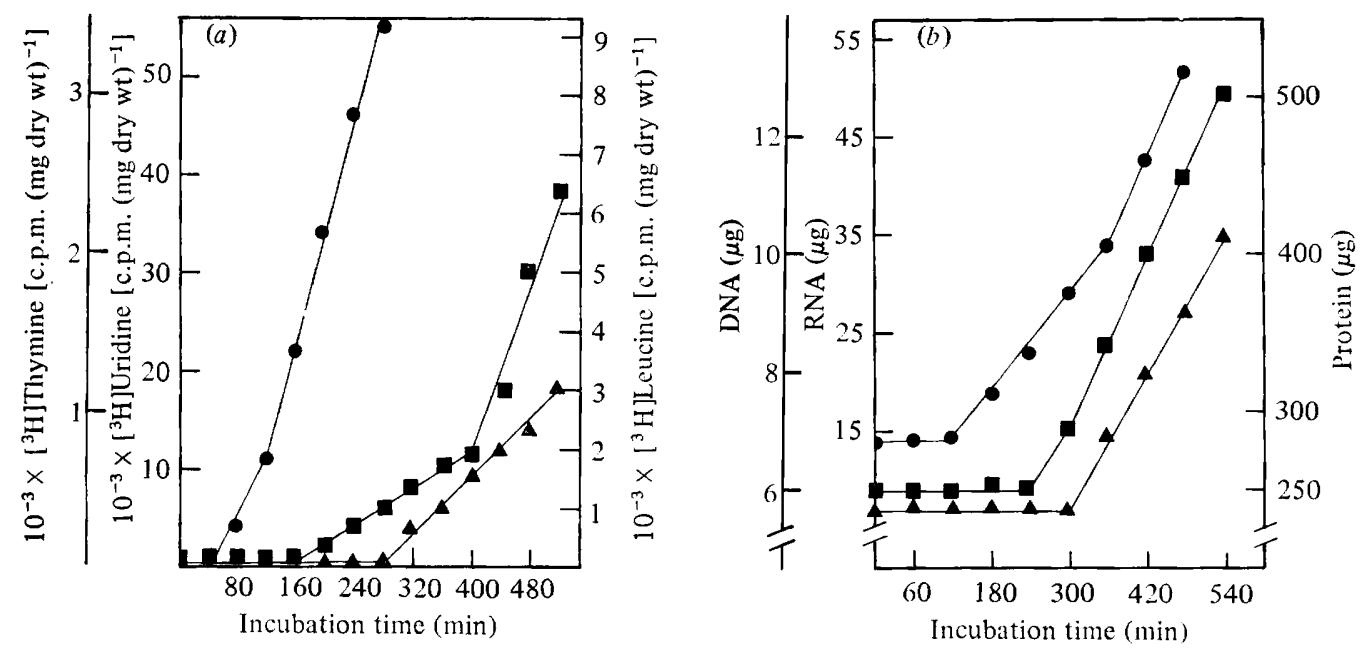

Fig. 5. Kinetics of RNA ( ), DNA (A) and protein ( $\mathbf{\square})$ synthesis during germination of Micromonospora chalcea spores. (a) Measured by incorporation of exogenous labelled precursors. Spores were incubated in GAE medium containing $5 \mu \mathrm{Ci}(185 \mathrm{kBq})$ of labelled precursor from the onset of germination. (Precursors were, respectively: $\left[5-{ }^{3} \mathrm{H}\right]$ uridine, sp.act. $24 \mathrm{Ci} \mathrm{mmol}^{-1}$; [6- $\left.{ }^{3} \mathrm{H}\right]$ thymine, sp.act. $20 \mathrm{Ci} \mathrm{mmol}^{-1}$; [4- $\left.{ }^{3} \mathrm{H}\right]$ leucine, sp.act. $50 \mathrm{Ci} \mathrm{mmol}^{-1}$.) At the indicated times, $1 \mathrm{ml}$ samples were taken and analysed as outlined in Methods. (b) Measured by chemical methods. At the indicated times, samples of $2 \times 10^{10}$ spores were collected by centrifugation, washed twice in saline solution and suspended in cold $0.1 \mathrm{M}$-Tris/ $\mathrm{HCl} \mathrm{pH} \mathrm{7.3} \mathrm{containing} \mathrm{1.25} \mathrm{mM-EDTA.} \mathrm{Macromolecules} \mathrm{were}$ extracted and estimated as described in Methods.

synthesis was RNA, protein and finally DNA. Synthesis of RNA, measured by $\left[{ }^{3} \mathrm{H}\right]$ uridine incorporation, started after about $80 \mathrm{~min}$ incubation, and initially was high (Fig. $5 a$ ). Protein synthesis, measured by $\left[{ }^{3} \mathrm{H}\right]$ leucine incorporation, showed two different slopes; the lower one started after $200 \mathrm{~min}$ incubation and lasted until $400 \mathrm{~min}$, and then a second, more active, period occurred during germ tube emergence (Fig. $5 a$ ). The incorporation of $\left[{ }^{3} \mathrm{H}\right]$ thymine in DNA started after $300 \mathrm{~min}$ incubation (Fig. $5 \mathrm{a}$ ). Measurement of synthesis of macromolecules by chemical methods gave similar results except for slight lag periods, which were probably due to the lower sensitivities of the methods (Fig. $5 b$ ). The rate of synthesis of macromolecules was also determined by pulse-labelling experiments. The synthesis of RNA (Fig. 6a) showed two stages. During the first, the incorporation rate increased until about $300 \mathrm{~min}$, the time at which the number of swollen spores reached a maximum. The second stage started during germ tube emergence and showed maximal and constant rates of incorporation. No more than $6 \%$ of the available label was incorporated during this experiment. Protein synthesis (Fig. 6b) occurred at different rates. Initially the rate was low and constant but after $400 \mathrm{~min}$ it increased linearly. DNA synthesis started after about $320 \mathrm{~min}$, the time at which outgrowth began, and soon reached constant values.

\section{Effect of inhibitors on macromolecular synthesis during germination}

When added at the onset of germination, rifampicin $\left(5 \mu \mathrm{g} \mathrm{ml}^{-1}\right)$ immediately prevented the incorporation of label into all three macromolecules; streptomycin $\left(5 \mu \mathrm{g} \mathrm{ml}^{-1}\right)$ and mitomycin $\mathrm{C}\left(5 \mu \mathrm{g} \mathrm{ml}^{-1}\right)$ both immediately inhibited protein and DNA synthesis but $\left[{ }^{3} \mathrm{H}\right]$ uridine incorporation was not blocked until 140 to $160 \mathrm{~min}$ after their addition (Fig. 7). Similar results were obtained when the antibiotics were added at different times during germination. 

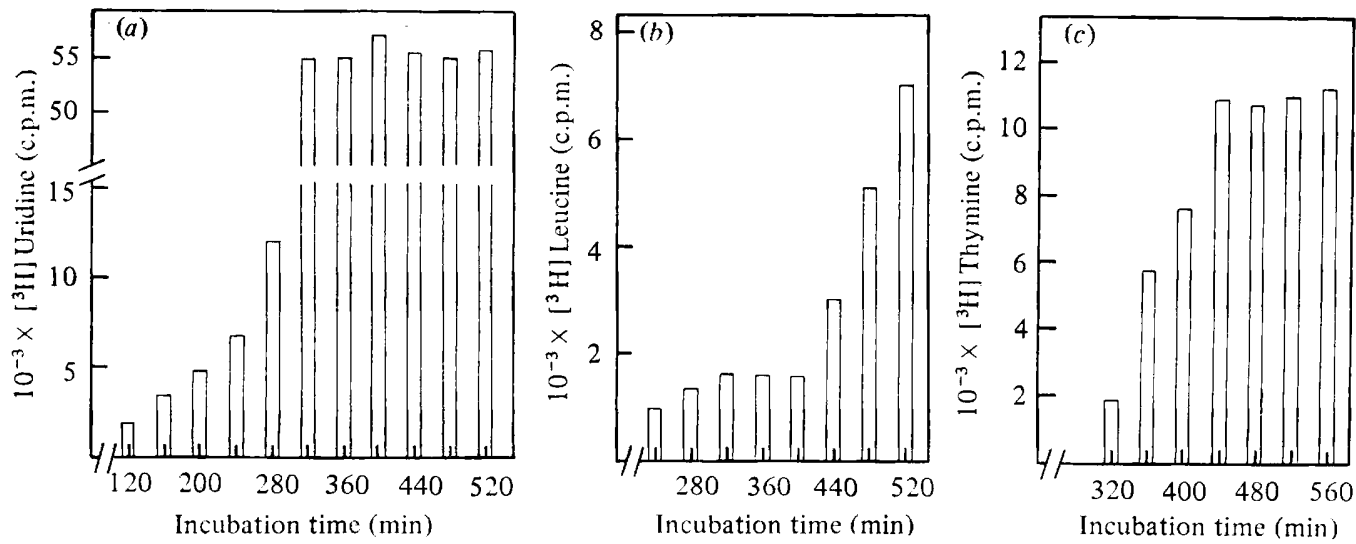

Fig. 6. Pulse-labelling patterns for RNA (a), protein (b) and DNA (c) synthesis during germination of Micromonospora chalcea spores. Samples $(1 \mathrm{ml})$ were taken at 40 min intervals from the start of germination, incubated with labelled precursors for $5 \mathrm{~min}$ and assayed for radioactivity. Where no bars are shown, no radioactivity was detected.

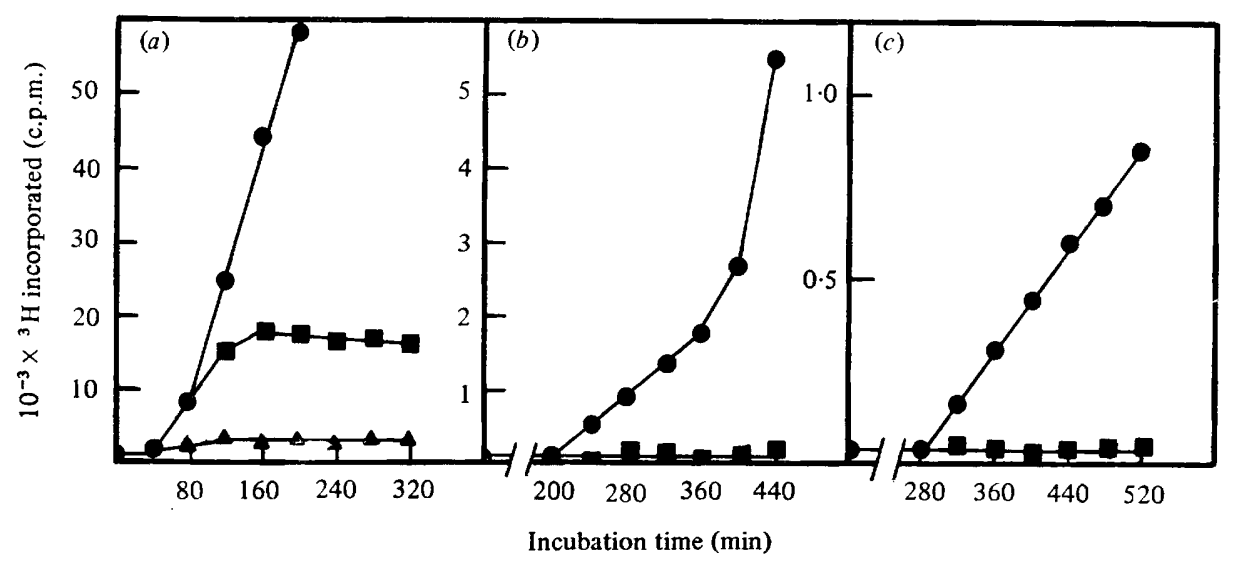

Fig. 7. Effect of rifampicin, streptomycin and mitomycin $\mathrm{C}\left(5 \mu \mathrm{g} \mathrm{ml}^{-1}\right)$ added at the onset of germination on the incorporation of labelled precursors into RNA $(a)$, protein $(b)$ and DNA $(c)$. (a): $\boldsymbol{O}$, control; $\boldsymbol{\square}$, streptomycin or mitomycin $\mathrm{C} ; \boldsymbol{\Delta}$, rifampicin. (b and $c)$ : $\boldsymbol{\boldsymbol { O }}$, control; $\boldsymbol{\square}$, streptomycin, mitomycin $\mathrm{C}$ or rifampicin.

\section{DISCUSSION}

During germination, Micromonospora chalcea spores pass through three morphological stages - darkening, swelling and germ tube emergence - as has been reported for Streptomyces (Attwell \& Cross, 1973; Ensign, 1978; Hardisson et al., 1978; Kalakoutskii \& Agre, 1976). The spores of $M$. chalcea appeared highly refractile and had characteristic properties of a dormant cell, such as a very low $Q_{\mathrm{o}_{2}}$, higher heat resistance than the vegetative form and impermeability to basic dyes. These properties could be due to an extreme dehydration of the cytoplasm which may be explained by a mechanism similar to the hypothesis of the expanded cortex for endospores (Gould \& Dring, 1975). The dormant spore of $M$. chalcea exhibits a large thickening of the inner layer of the wall (Hardisson \& Suárez, 1979). Several features of $M$. chalcea spore germination were similar to those of $S$. antibioticus spores (Hardisson et al., 1978). These included nutritional requirements for germination, effects of inhibitors and the sequence of macromolecular synthesis. However, the process was considerably slower in $M$. chalcea. 
Spore darkening was accompanied by a loss of refractility and a decrease in absorbance. The requirements for darkening and the properties of the spores at this stage were basically similar to those found in S. antibioticus (Hardisson et al., 1978). Activation treatments such as heating, freezing and ultrasonication had no effect on spore germination. Therefore $M$. chalcea could be included in the group of organisms with an exogenous dormancy (Kalakoutskii \& Agre, 1976; Sussman \& Halvorson, 1966). Once the spores had darkened they began to swell, requiring an exogenous supply of energy, such as glucose. However, a nitrogen source was not required. Swollen spores showed the highest cytochrome oxidase, catalase and respiratory activities. A similar pattern has been observed in other actinomycetes (Hardisson et al., 1978; Kalakoutskii \& Pouzharitskaja, 1973). Swelling was dependent on new RNA synthesis, inhibitors such as rifampicin or actinomycin D completely blocking germination at this stage. The same results were obtained with $S$. antibioticus spores (Hardisson et al., 1978), but not with S. granaticolor (Mikulik et al., 1977), where rifampicin only blocked germ tube emergence. Protein synthesis that started during swelling must have aided it, because swelling was retarded by the addition of streptomycin. Mitomycin $\mathrm{C}$, which rapidly inhibits $\left[{ }^{3} \mathrm{H}\right]$ leucine incorporation, had a similar effect. Furthermore, this protein synthesis was independent of the supply of any external nitrogen source. Similar results were found in S. antibioticus (Hardisson et al., 1978).

Germ tube emergence was dependent on both carbon and nitrogen sources, and during this stage dry weight increased linearly. DNA synthesis started at this stage after about 300 min incubation, and soon reached constant values. The apparent delay between the low initial rate of synthesis and the later constant and higher rate could be due to a lack of synchronization of the germinating spore population. Initiation of DNA synthesis also coincides with outgrowth in dormant cells of many other bacteria, such as Bacillus (Steinberg \& Halvorson, 1968), Azotobacter (Loperfido \& Sadoff, 1973) and Streptomyces (Hardisson et al., 1978).

The sequence of macromolecular synthesis during the germination of $M$. chalcea spores was RNA, protein and DNA. A similar pattern of synthesis has been observed during the germination of Bacillus endospores (Kobayashi et al., 1965), Azotobacter cysts (Loperfido \& Sadoff, 1973) and Streptomyces spores (Hardisson et al., 1978). With respect to the effect of inhibitors of macromolecular synthesis, it may be emphasized that mitomycin $\mathrm{C}$, a specific inhibitor of DNA replication (Iyer \& Szybalsky, 1963), and streptomycin had a similar effect in all the situations tested. This could be explained by the fact that mitomycin $\mathrm{C}$ may have a direct effect on protein synthesis by acting on the ribosomes, as was shown in Escherichia coli (Suzuki \& Kilgore, 1967).

\section{REFERENCES}

AtTwell, R. W. \& Cross, T. (1973). Germination of actinomycete spores. In The Actinomycetales: Characteristics and Practical Importance, pp. 197-207. Edited by G. Sykes \& F. A. Skinner. London \& New York: Academic Press.

Burton, K. (1956). Study of the condition and mechanism of the diphenylamine reaction for the colorimetric estimation of DNA. Biochemical Journal 62, 315-323.

ENSIGN, J. C. (1978). Formation, properties and germination of actinomycete spores. Annual Review of Microbiology 32, 185-219.

GouLD, G. W. (1971). Methods for studying bacterial spores. Methods in Microbiology 6A, 327-381.

Gould, G. W. \& DrING, G. J. (1975). Heat resistance of bacterial endospores and the concept of an expanded osmoregulatory cortex. Nature, London 258, 402-405.
Hardisson, C. \& Suárez, J. E. (1979). Fine structure of spore formation and germination in Micromonospora chalcea. Journal of General Microbiology 110, 233-237.

Hardisson, C., Manzanal, M. B., Salas, J. A. \& SuÁrez, J. E. (1978). Fine structure, physiology and biochemistry of arthrospore germination in Streptomyces antibioticus. Journal of General Microbiology 105, 203-214.

IYER, V. N. \& SZYBALSKY, N. (1963). A molecular mechanism of mitomycin-action linking of complementary DNA strands. Proceedings of the National Academy of Sciences of the United States of America 50, 355-362.

Kalakoutskin, L. V. \& Agre, N. S. (1976). Comparative aspects of development and differentiation in actinomycetes. Bacteriolosical Reviews 40, 469-524 
KalakoutskiI, L. V. \& Pouzharitskaja, L. M. (1973). The Streptomyces spore: its distinct features and germinal behaviour. In The Actinomycetales: Characteristics and Practical Importance, pp. 155-178. Edited by G. Sykes \& F. A. Skinner. London \& New York: Academic Press.

Kobayashi, Y., Steinberg, W., Higa, A., Halvorson, H. O. \& Levinthal, C. (1965). Sequential synthesis of macromolecules during outgrowth of bacterial spores. In Spores III, pp. 200-212. Edited by L. L. Campbell \& H. O. Halvorson. Ann Arbor, Michigan: American Society for Microbiology.

LOPERFIDO, B. \& SADOFF, H. L. (1973). Germination of Azotobacter vinelandii cysts: sequence of macromolecular synthesis and nitrogen fixation. Journal of Bacteriology 113, 841-846.

Mikulik, K., Janda, I., Maskova, H., Stastna,
J. \& JiRINova, A. (1977). Macromolecular synthesis accompanying the transition from spores to vegetative forms of Streptomyces granaticolor. Folia microbiologica 22, 252-261.

SCHNEIDER, W. C. (1957). Determination of nucleic acids in tissues by pentose analysis. Methods in Enzymology 3, 680-689.

SteinberG, W. \& Halvorson, H. O. (1968). Timing of enzyme synthesis during outgrowth of spores of Bacillus cereus. II. Relationship between ordered enzyme synthesis and DNA replication. Journal of Bacteriology 95, 479-489.

Sussman, A.S. \& Halvorson, H. O. (1966). Spores, Their Dormancy and Germination. New York: Harper \& Row.

Suzuki, H. \& Kilgore, W. W. (1967). Decomposition of ribosomal particles in Escherichia coli treated with mitomycin C. Journal of Bacteriology 94, 666-676. 